\title{
Treatment of Heart Failure with Autologous Skeletal Myoblasts
}

\author{
Juan C. Chachques' ${ }^{1}$ Barbara Cattadori', Jesus Herreros ${ }^{2}$, Felipe Prosper², Jorge C. Trainini', \\ Didier Blanchard ${ }^{1}$, Jean-Noël Fabiani', Alain Carpentier ${ }^{1}$
}

Background: The management of patients with heart failure is a daily challenge for cardiologists and cardiac surgeons. Pharmacotherapy, atrio-biventricular resynchronization, myocardial revascularization, valve repair techniques, latissimus dorsi cardiomyoplasty, acorn cardiac support device, heart transplantation and mechanical assist devices do not cover all the needs. The recent progress in cellular and molecular biology allows the development of new therapies for heart failure. Transplantation of Autologous Cells: One of the most innovative consists in the transplantation of autologous ex-vivo expanded cells into the myocardium for heart muscle regeneration. This approach is called "cellular cardiomyoplasty".

Key Words: Cellular cardiomyoplasty · Cellular biology · Myoblasts · Cell transplantation · Myocardial infarction · Congestive heart failure

Herz 2002;27:570-8

DOI $10.1007 / \mathrm{s} 00059-002-2422-3$

\section{Behandlung der Herzinsuffizienz mit autologen Skelettmyoblasten}

Hintergrund: Die Behandlung der Herzinsuffizienz stellt trotz Pharmakotherapie, biventrikulärer Resynchronisation, interventioneller und kardiochirurgischer Revaskularisation, der Latissimus-doris-Kardiomyoplastie, der kardialen Assist-Systeme und der Herztransplantation unverändert eine therapeutische Herausforderung an Kardiologen und Herzchirurgen dar. Neue molekularbiologische Techniken sind die Voraussetzung für innovative Therapieansätze. Zu ihnen gehört die autologe Myoblastentransplantation von ex vivo expandierten Skelettmuskelzellen ins Myokard zur Herzmuskelregeneration.

Autologe Myoblastentransplantation: Vor den von der Arbeitsgruppe an der Universität Paris (Klinik Broussais) durchgeführten ersten drei Transplantationen von Skelettmuskelmyoblasten beim Menschen wurden u.a. Erfahrungen am Kardiotoxinmodell des Schafs vor und nach Myoblastentransplantation mittels Kolorkinesis-Echokardiograpie (Abbildung
4) gesammelt. Die herzkatheterbasierte Applikation von Myoblasten wurde am gleichen Modell unter Verwendung des Noga-Systems (Abbildung 5) zum elektroanatomischen „Mapping" erfolgreich erprobt und die Verbesserung der regionalen Wandbewegung durch biventrikuläre Stimulation gezeigt. Eine De-novo-Angiogenese zeigte sich nur nach Vorbehandlung der Tiere mit VGEF. Der Erfolg einer Myoblastentransplantation hängt von der Zahl überlebender injizierter Myoblasten ab. Dies ist in der Randzone eines Infarkts oder bei experimenteller „Pacing-induzierter“ dilatativer Kardiomyopathie besser als im Bereich einer Narbe. Bei den bisher drei am Menschen vorgenommenen autologen Transplantation von Skelettmuskelmyoblasten konnte eine Reduktion der Infarktgröße erreicht werden. Die Expansion der Myoblasten im autologen Serum ist dabei zur Vermeidung von immunologischen $\mathrm{Ab}$ wehrmechanismen, die unter bovinem Serumalbumin als Nährmedium gezeigt wurden, von besonderer Bedeutung.

Schlüsselwörter: Zelluläre Kardiomyoplastik · Zellbiologie $\cdot$ Myoblasten · Zelltransplantation · Herzinfarkt · Herzinsuffizienz

\footnotetext{
${ }^{1}$ Department of Cardiac Surgery, Pompidou and Broussais Hospitals,

University of Paris, France,

${ }^{2}$ University of Navarra, Spain.
} 


\section{Introduction}

Cellular cardiomyoplasty (CMP) consists of cell implantation intended to induce the growth of new muscle fibers and the development of angiogenesis in the damaged myocardium that potentially may contribute to the contractile performance of the heart [1]. Adult myocardium cannot effectively repair after infarction due to the limited number of stem cells [2]. Thus, most of the injury is irreversible. For this reason, cell transplantation strategies for heart failure have been designed to replace damaged cells with cells that can perform cardiac work, either in ischemic or idiopathic cardiomyopathies [3].

Tissue regeneration techniques based on cell transplantation technology have been previously used with excellent long-term results for treatment of hemopathies (chronic lymphocytic leukemia, aplastic anemia, immunodeficiencies, myeloma). Cell-based therapy is in development for other pathologies as neurodegenerative diseases (Huntington and Parkinson diseases, spinal cord regeneration), hepatology (implantation of hepatocytes as a bridge to liver transplantation), diabetes mellitus (transplantation of Langerhans islets), myology (transplantation of myoblasts in Duchenne dystrophy), dermatology (implantation of cultured fibroblasts for dermal regeneration followed by keratinocyte implantation for epidermal regeneration) and in orthopedics (implantation of chondrocytes for repair of articular defects of the knee). Interestingly, autologous cultured chondrocytes had been recently proposed for lining the luminal surfaces of cardiovascular prostheses, in order to provide a strongly adherent artificial surface [4].

\section{Epidemiology}

Ischemic myocardial disease, the main cause of heart failure, is a major public health and economic problem. Currently CABG is one of the most common major surgical procedure in the United States and Western Europe, with over 200,000 procedures performed each year. When comparing changes in quality of life of patients suffering from several chronic medical conditions, heart failure patients consistently report the greatest deterioration. Heart failure is a potentially lethal disease, the 5-year mortality rate is approximately $50 \%$. Among those with severe heart failure, the survival rate at 3 years is only $25 \%$. In view of the poor prognosis and poor quality of life of patients with chronic heart failure, it is appropriate that we review the role of new surgical procedures in preventing recurrent heart failure. The shortage of donors for heart transplantation compared to the increase of numbers of potential recipients is the most notorious problem for the terminal state of heart failure $[5,6]$.

\section{Cellular Cardiomyoplasty}

Cellular cardiomyoplasty is a combination of cellular biology with cardiac surgery or with interventional cardiology. Its aim is to regenerate the myocardium in order to prolong and improve the quality of life of patients who suffer from severe chronic cardiac deficiency and who are unresponsive to medical treatment. In cellular cardiomyoplasty, the cells of the same subject are used to regenerate the myocardium which excludes the risk of rejection and, therefore, no immunosuppressive treatment is necessary [7-9].

\section{Mechanisms of Beneficial Effects}

The many proposed mechanisms of action of cellular cardiomyoplasty are specified in Table 1.

Postischemic ventricular remodeling and diastolic dysfunction are increasingly recognized as causes of symptomatic heart failure. Conditions associated with diastolic dysfunction are diverse and most commonly include ischemic cardiomyopathy with previous myocardial infarction(s) and hypertensive heart disease. An underlying histopathologic finding is an adverse accumulation and structural remodeling of the heart's fibrillar collagen matrix expressed as cardiac fibrosis [10]. Cell-based procedures should replace fibrosis by living tissues, thus improving the rate of relaxation, diastolic suction and passive stiffness [11].

\footnotetext{
Table 1. Cellular cardiomyoplasty: Mechanisms of beneficial effects. Tabelle 1. Zelluläre Kardiomyoplastik: Mechanismen und positive Effekte.

Ventricular remodeling:

Reduces the size and fibrosis of infarct scars

Minimizes global ventricular dilatation

Increases myocardial wall thickness

Avoids postischemic remodeling

Diastolic function:

Improves myocardial wall tension and elasticity

Improves strain and dynamic stiffness

Reverses diastolic creep

Systolic function:

Improves regional ventricular wall motion

Increases developed pressures

Improves global ventricular contraction?
} 


\section{Cells for Myocardial Regeneration}

Current possibilities in cell therapy for heart failure are the transplantation into the damaged myocardium of different cell types: autologous myoblasts (satellite cells originated from skeletal muscle), bone marrow-derived stem cells, peripheral blood-derived stem cells, smooth muscle cells, angioblasts and endothelial cells.

The two most investigated cells for myocardial repair are skeletal myoblasts and bone marrow stem cells. The major drawback for myoblasts is that these cells do not contract spontaneously. Electrostimulation was proposed by our group to transform passive cell therapy into "dynamic cellular support" [12]. Bone marrow stem cells can undergo milieu-dependent differentiation: When transplanted in normal myocardium they can become cardiocytes, but when these cells are implanted in a myocardial scar they may differentiate into fibroblasts, becoming a "scar within a scar". Stem cells can be experimentally cultured and induced to differentiate to a myogenic phenotype with 5-azacytidine. Co-cultures of cardiomyocytes with stem cells had been proposed for cell pre-differentiation [13-15].

\section{Indications}

Ischemic Cardiomyopathy

Patients in NYHA FC 2 or 3, presenting impaired left ventricular function (ejection fraction between $20 \%$ and $40 \%$ ), left ventricular wall postischemic scars (akinetic and metabolically non-viable) are candidates for cellular cardiomyoplasty. Ventricular wall thickness at echocardiographic evaluation should be $>4 \mathrm{~mm}$. Right ventricular infarction is also an indication for cellular cardiomyoplasty. Concomitantly, patients can present indications for $\mathrm{CABG}$ in remote, viable and ischemic areas.

\section{Idiopathic Dilated Cardiomyopathy}

Non-ischemic cardiomyopathy is also a frequent cause of congestive heart failure. Cell transplantation could offer new hopes in this disease by restoring impaired systolic and diastolic functions. Interestingly, the grafted cells appear to better survive in the host myocardium because myocardial irrigation in this pathology is not significantly impaired [16].

\section{Methods and Procedures in Cellular Cardiomyoplasty}

Cell-based therapies for heart diseases were conceived to reverse the damage dysfunctional myocardial tissue into a living histological structure, capable of generating
Table 2. Cellular cardiomyoplasty procedure.

Tabelle 2. Zelluläre Kardiomyoplastik: Methodik.

1. Removal of fibrous and adipose tissue from muscle biopsy

2. Muscle mincing with scissors

3. Enzymatic (collagenase + trypsin) and mechanical digestion

4. Multiple centrifugations

5. Isolation of myoblasts, exclusion of fibroblasts

6. In-vitro myoblasts culture: incubation during 3 weeks in humidified atmosphere, at $37^{\circ} \mathrm{C}, 5 \% \mathrm{CO}_{2}$

7. Assessment of percent cell viability (trypan blue)

8. Assessment of percent myoblasts/fibroblasts (CD56 antibodies + flow cytometry, desmin antibody)

9. Sterility tests: bacterial viral, fungal

10. Cell suspension in $0.5 \%$ human albumin for myocardial injection

improved systolic and diastolic ventricular pressures. The cellular cardiomyoplasty procedure using myoblasts consists: a) in a surgical biopsy of $10-15 \mathrm{~g}$ of a skeletal muscle (e.g., the thigh vastus lateralis muscle), b) in-vitro expansion of cells during 2-3 weeks, and, c) the implantation of these cells into the ventricular wall.

To perform a cellular cardiomyoplasty procedure using autologous myoblasts the steps described in Table 2 must be followed.

\section{Skeletal Muscle Biopsy}

3 weeks before the cellular cardiomyoplasty procedure, under local anesthesia using lidocaine (2\%) injected into and around the selected muscle, a biopsy sample of the thigh vastus lateralis muscle is taken through a $5 \mathrm{~cm}$ incision (Figure 1). A $2-3 \mathrm{~cm}^{3}$ skeletal muscle piece (15 $\mathrm{g}$ ) is explanted under sterile conditions. Immediate fragmentation of the muscle with scissors is performed, then it is introduced in complete culture medium or in PBS (phosphate buffer solution) and kept at $4^{\circ} \mathrm{C}$. The operative wound is closed. The procedure for cell isolation

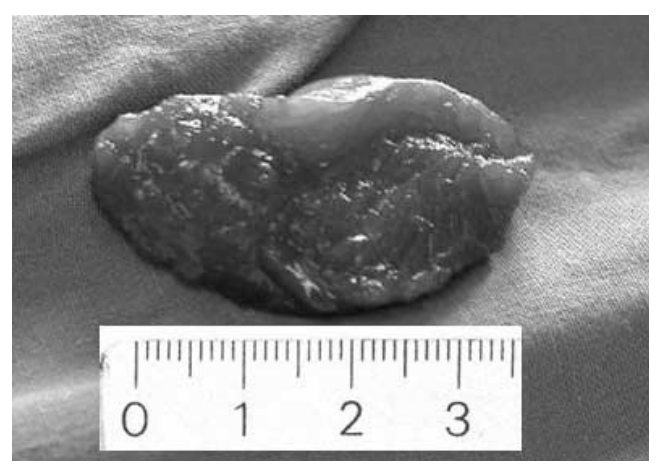

Figure 1. Muscular biopsy from the thigh vastus lateralis. Abbildung 1. Skelettmuskelbiopsie vom Musculus vastus lateralis. 

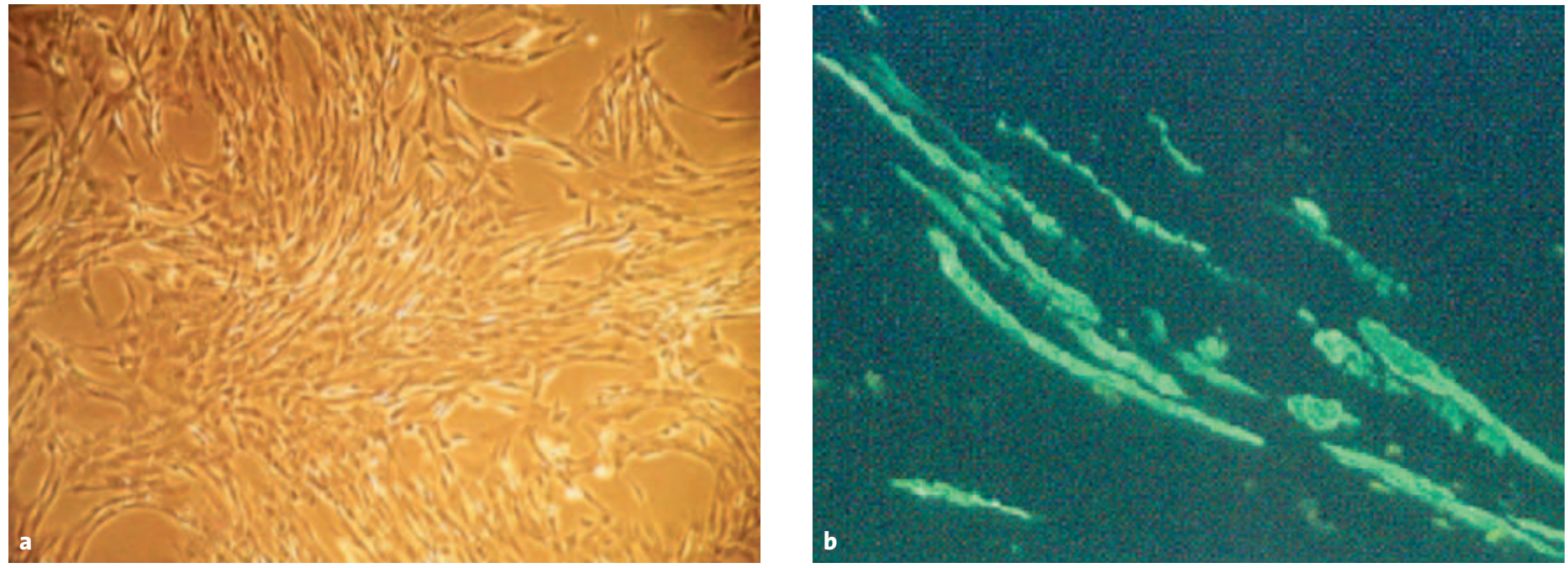

Figures $\mathbf{2 a}$ and $\mathbf{2 b}$. a) Cultured myoblasts (satellite cells) ready to be transplanted into the myocardium. b) Histological study showing myotubes developed 6 months after myoblasts implantation in a myocardial infarct.

Abbildungen 2a und 2b. a) Myoblastenkulturen (Satellitenzellen) unmittelbar vor Transplantation ins Myokard. b) Histologischer Nachweis von Myotubes 6 Monate nach Implantation von Myoblasten in ein Infarktgewebe.

and culture should start as soon as possible, so as to guarantee cell survival. However, samples can be carried in an appropriate container at low temperature, and then transported to the cellular biology laboratory.

\section{Injection Medium}

On the day of transplantation, cells are harvested and washed in the injection medium (human albumin $0.5 \%$ + complete culture medium) and kept in ice before implantation. A sample is performed to assess final myoblasts rate by flow cytometry test (percentage of myoblasts CD56-positive/desmin-positive cells (Figures 2a and $2 b$ ). The cell concentration and viability are determined with trypan blue using a Malassez cytometer. Sterility of cell culture is also assessed before implantation (Gram tests) (Table 3).

\section{Cell Implantation Procedure}

Cellular implantation can be performed through an epicardial or an endovascular delivery approach. The epicardial approach (Figure 3) can be performed either by

Table 3. Myoblast implantation protocol.

Tabelle 3. Myoblastenimplantation. Protokoll.

Impantation of $>200$ million cells

Density of cells: 50-70 million cells per $\mathrm{ml}$

Time to culture: approximately 21 days

Myoblast concentration of $>70 \%$ myoblasts

Cell shelf life at $2-8^{\circ} \mathrm{C}$ are 96 hours conventional surgical exposure or thoracoscopy. In the surgical approach (classic or mini-thoraco/sternotomy) the ischemic area is well exposed thus permitting around ten injections of cells suspended in $0.5 \%$ human albumin (diluted in culture medium) in and principally around the infarction, with a $23-26 \mathrm{G} \times 4 \mathrm{~cm}$ curved needle (e.g., $25 \mathrm{G} \times 40 \mathrm{~mm}$ retrobulbar ophthalmic nee-

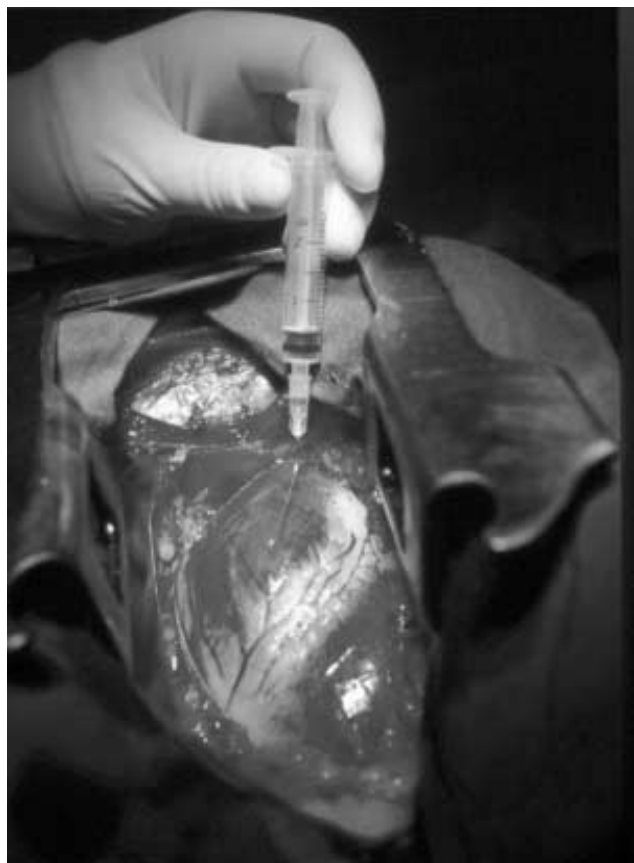

Figure 3. Transepicardial injection of cells, using a $25 \mathrm{G} \times 40 \mathrm{~mm}$ retrobulbar ophthalmic needle.

Abbildung 3. Transepikardiale Zellinjektion mit einer $25 \mathrm{G} \times 40 \mathrm{~mm}$ retrobulären ophthalmischen Kanüle. 
dle). Recommended density of cells is between 50 and 70 million cells per $\mathrm{ml}$. The cell injection procedure should be performed slowly and carefully, taking approximately 15 minutes. Cells should be delivered when the $4 \mathrm{~cm}$ needle is slowly removed from the myocardium. To improve injectate retention, needle holds should be compressed with a finger 1-2 minutes after every injection, in order to avoid regurgitation of the cell solution (channel leakage).

Cell mortality after transplantation seems to be important when they are grafted into high-fibrotic ischemic scars, since there are a great limitation of oxygen and nutrients supply to the chronic ischemic myocardium. Our approach consists in performing the main cell implantation in the periinfarct area ( $70 \%$ of cells), since the residual irrigation and collateral myocardial revascularization in this intermediate area allows a better survival of the implanted cells. The remaining $30 \%$ of cells are implanted in the central part of the scar. The effects of this cell implantation procedure will be the centripetal reduction of the infarct area. For idiopathic dilated cardiomyopathies, multiple cell injections between the coronary arteries should be performed in the myocardium of both ventricles. The grafted cells should survive better in the host myocardium because myocardial irrigation in non ischemic cardiomyopathies is not significantly impaired [16].

\section{Laboratory Investigations at University of Paris (Broussais Hospital)}

\section{Evaluation of Regional Myocardial Function after} Cellular Therapy in a Cardiotoxin Model

The aim of cell transplantation into pathologic myocardium is to repair, replace or enhance the biological function of the altered ventricle, restoring a functional myocardial mass, and hence improving the contractile performance of the heart. In this study a reproducible method for the creation of a myocardial lesion was developed [9]. The functional benefit of cell implantation was evaluated by two-dimensional echocardiography for global contraction and color-kinesis echocardiography (CK, Hewlett Packard Sonos 5500), which allows the precise assessment of the regional contraction (Figure 4).

Methods: A left ventricular intramyocardial injection (3 mg/1.5 ml) of snake cardiotoxin (C 9759, Sigma Chem.) was carried out on a sheep model to induce a well-delineated transmural lesion. 3 weeks later, the lesion was assessed by echocardiography. Thereafter, au-

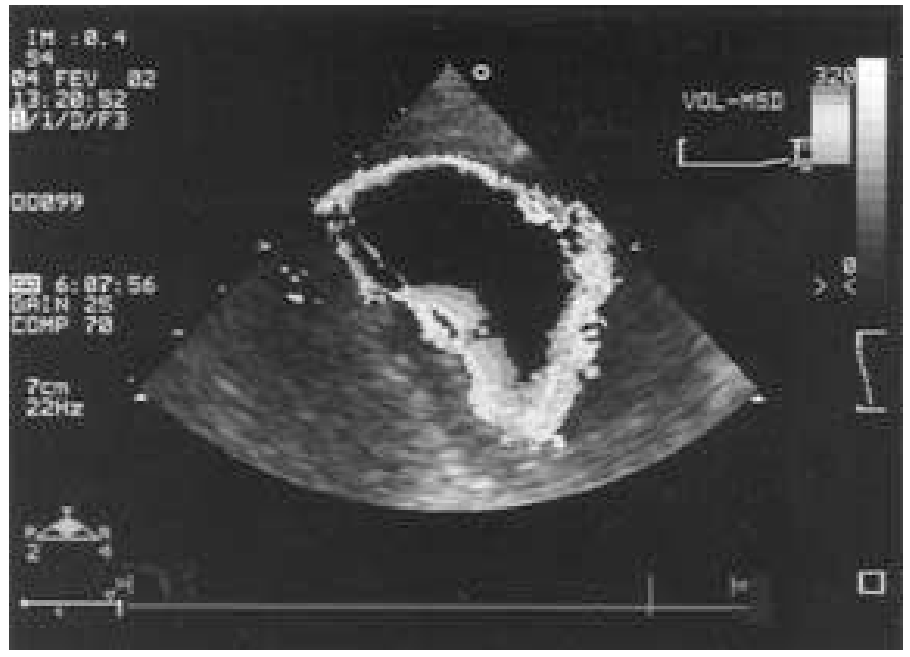

Figure 4. Color-kinesis echocardiography: assessment of regional fraction area change (RFAC) in a myocardial infarction model.

Abbildung 4. Kolorkinesis-Echokardiographie: Bestimmung der Änderung der regionalen Flächen der Wandbewegung in einem Infarktmodell.

tologous skeletal muscle cells (myoblasts) or culture media (control) were injected into the lesion. 2 months after cell implantation, the myocardial contraction was again evaluated by echocardiography and the implanted cells were analyzed by a fast myosin heavy chain antibody.

Results: The snake cardiotoxin produced a well-delineated transmural lesion in all animals. Echocardiographic studies showed a significant improvement in global and regional left ventricular function (RFAC) in cell-treated sheep. Histologic analyses demonstrated satellite cell survival, principally at the periphery of the lesions.

Conclusions: Satellite cells implanted in a cardiotoxin-induced myocardial lesion survived for a 2month period and were associated with a significant functional improvement of both local and global contraction. Local cardiotoxin administration generated transmural necrosis, with severe damage of cardiomyocytes and interstitial tissues (myocardial matrix).

\section{Catheter-Based Cell Implantation for Myocardial Regeneration}

We studied the possibility of endoventricular cell implantation in an experimental model of myocardial infarction [17]. Cell implantation was performed using a specific catheter (Noga Biosense, Cordis Inc) guided by electroanatomical mapping (Figures 5a and 5b).

Methods: To evaluate potential cell damage during the implantation process, we tested in vitro the injection 

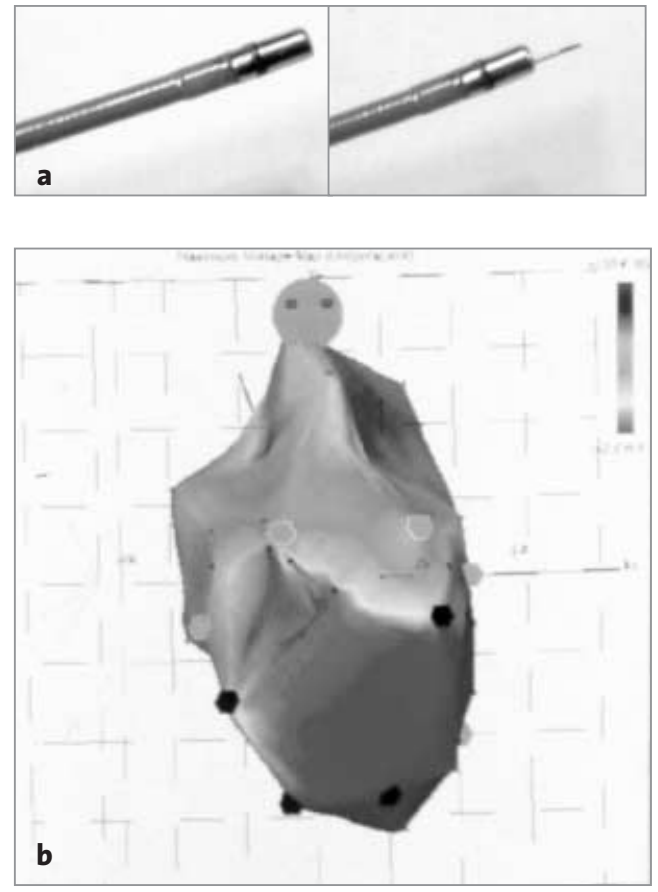

Figures $\mathbf{5}$ a and $\mathbf{5 b}$ b. a) Percutaneous Noga biosense catheter, used to deliver cells into the myocardium from the left ventricular chamber. $b$ ) Electroanatomical mapping of the heart showing the left ventricular myocardial infarction (red area in the apex) and four cell injection points (black points).

Abbildungen 5a und 5b. a) Perkutaner Noga-Biosense-Katheter, der für myokardiale Applikation der Myoblasten aus dem linken Ventrikel verwendet wird. b) Elektroanatomisches Mapping des Herzens: Die rote apexnahe Fläche zeigt das Infarktgebiet, die schwarzen Punkte die vier Stellen der Myoblasteninjektion.

of the cell suspension through the catheter. Afterwards, in seven sheep we created a myocardial infarction by ligation of two coronary branches. From a muscle biopsy myoblasts were isolated and spread in culture for 3 weeks up to 50 million cells. In two sheep methylen blue was injected in the myocardial scars by the catheter. In five sheep the cells were implanted using this endoventricular approach. At 2 months, histological and immunohistological studies were performed.

Results: In-vitro studies of catheters showed a low residual volume of $70 \mu \mathrm{l}$, with cell integrity being preserved. Methylen blue was detected in the infarcted areas. Viable myoblasts were detected in the myocardium and scar using specific antibodies.

Conclusions: The Biosense system with electromechanical mapping of the heart allows the precise guidance of the catheter to the infarcted zone. Viable cells were detected in the implantation sites. Periodically repeated cell implantation procedures could be performed with this system.

\section{Myocardial Electrostimulation after Cellular Cardiomyoplasty}

The principles of electrophysiological conditioning of muscle fibers were applied by our group in cellular cardiomyoplasty since skeletal myofibers express predominantly fatigue-sensitive fast myosin, which is not suitable for cardiac work. Atrial synchronized biventricular pacing is indicated in heart failure patients to correct conduction disorders associated with chronic systolic and diastolic dysfunction. We explored the possibility to electrostimulate the ventricles following autologous skeletal myoblast implantation to create an active cellular cardiac support, since skeletal myoblasts are known not to contract spontaneously [12].

Methods: 22 adult sheep were included. All animals underwent myocardial infarction by ligation of two coronary arteries (distal LAD and D2). After 3 weeks, autologous cultured myoblasts were injected in the infarcted areas. Atrial synchronized biventricular pacing (BIV) was performed using epicardial electrodes, with a pulse amplitude of $5 \mathrm{~V}$ and a pulse width of $0.5 \mathrm{~ms}$. Ventricular electrostimulation includes depolarization of the implanted cells.

Results: Echocardiographic studies performed at 2 months showed a significant improvement in ejection fraction ( $47 \pm 6$ vs $36 \pm 4 \%$ ) and a limitation of left ventricular dilatation $(49 \pm 7$ vs $69 \pm 2 \mathrm{ml})$ in cell treated biventricular pacing vs control group. Viable cells were identified in the infarcted areas. Differentiation of myoblasts into myotubes was significantly improved in the group associating cell therapy with biventricular pacing, immunocytological studies showed enhanced expression of slow myosin heavy chain (MHC).

Conclusions: Electrostimulation induced the synchronous contraction of transplanted myoblasts, thus improving ventricular function. Histochemical studies after pacing demonstrated enhanced expression of slow MHC which is better adapted at performing cardiac work. Simultaneous cardiac resynchronization can also be achieved with this approach in order to correct conduction defects.

\section{Angiogenic Growth Factors vs Cellular Therapy for Myocardial Infarction}

Locally delivered angiogenic growth factors and cell implantation have been proposed for patients presenting myocardial infarcts without possibility of percutaneous or surgical revascularization. The goal of this study was 
to compare the effects of these techniques, in an experimental model of myocardial infarct [18].

Methods: 27 female sheep, weighing 21-34 kg, were divided into four groups: In Group I (control) a myocardial infarction was created and $0,5 \mathrm{ml}$ of culture medium was injected in the myocardial scar. In Group II a myocardial infarction was created and $100 \mu \mathrm{g}$ of VEGF (vascular endothelial growth factor) were injected at 3 weeks. In Group III satellite cell implantation was carried out 3 weeks after infarction. In Group IV cell were associated to VEGF and injected simultaneously into the scar.

Results: Three animals died intraoperatively. Serum troponin rose to $45.6 \pm 4.7 \mathrm{ng} / \mathrm{ml}$ at postinfarction day 2 . Echocardiography showed a significant limitation of left ventricular dilatation in the cell group: $57 \pm 5.5 \mathrm{ml}$ (control group: $74.4 \pm 5 \mathrm{ml}$, VEGF group: $68 \pm 1.6 \mathrm{ml}$ ), color-kinesis echo showed improvement of regional fraction area change (RFAC) only in the cell group, from $3.6 \pm 0.8$ to $21 \pm 1.5 \%, p<0.05$. The number of capillaries increased significantly in the periinfarct area of VEGF group: $1036 \pm 175$ (control group: $785 \pm$ 131, cell group: $830 \pm 75$ ). Myoblast implantation did not induce angiogenesis and angiogenic growth factors did not improve myocardial contractility and remodeling. Simultaneous delivery of VEGF and cells did not demonstrate beneficial effects.

Conclusions: Our results showed that cell therapy improves regional myocardial contractility and reverses left ventricular chamber remodeling. Angiogenesis was only demonstrated in animals treated with VEGF (not with cells). Any functional benefit was demonstrated in the group treated with growth factors. The association of VEGF with cells did not show beneficial effects. It can be concluded that growth factors should be delivered in myocardial infarction several days before cell transplantation in order to improve local conditions for cell survival (preconditioning).

\section{Cellular Therapy for Dilated Cardiomyopathy}

Dilated cardiomyopathy is the end-point of various pathologies affecting the myocardium [5]. We created an experimental model of dilated cardiomyopathy induced by ventricular rapid pacing to study the effects of cell therapy on non-ischemic heart failure.

Methods: Dilated cardiomyopathy was created in twelve sheep by implantation of two epicardial unipolar leads on the right ventricle and the insertion of a pulse generator into a subcutaneous pocket. Baseline mea- sures of left ventricular function were made. Ventricular pacing was initiated at a rate of $180 \mathrm{bpm}$ for 4 months, plus 1 month at $200 \mathrm{bpm}$. All animals were treated with $60 \mathrm{mg}$ of frusemide when heart failure symptoms appeared. Skeletal myoblasts (300 million) or culture medium (control) were transplanted after 2 weeks after inactivation of the pacemaker. At 3 months, hemodynamic studies (P-V loops), echocardiography (tissue Doppler), planimetry and histologic studies were performed.

Preliminary Results: Rapid ventricular pacing produced a dilated cardiomyopathy that was still present 2 weeks after the PM inactivation, but with a spontaneous tendency to reverse. Pressure/volume analysis showed a ventricular overload and ventricular relaxation dysfunction. Tissue velocity imaging (ultrasound technique) was used to provide quantitative information about regional systolic and diastolic myocardial motion, to assess the extension of ventricular injury and the degree of recovery in sheep. The rate of survival of implanted cells in non-ischemic cardiomyopahy may be better, since the myocardial irrigation is still preserved in this pathology.

\section{Clinical Experience}

In an attempt to repair damaged heart muscle and to improve cardiac function, we have transplanted patient's own skeletal muscle cells (autologous myoblasts) directly into infarcted left ventricular areas in five cases.

Patients: Procedures were performed in four male and one female patients, mean age 63 years, in NYHA functional class III, presenting impaired left ventricular function (ejection fraction $28 \pm 3 \%$ ), left ventricular posterior wall postischemic scars (akinetic and metabolically non-viable), and indications for CABG in remote, viable and ischemic areas. Procedures were approved by institutional review boards, informed written consent was obtained from each patient.

Procedure: During an outpatient procedure under local anesthesia, surgical biopsies of $12 \pm 3 \mathrm{~g}$ of a skeletal muscle (the thigh vastus lateralis muscle), were performed. In the cellular biology laboratory skeletal muscle stem cells (myoblasts) were isolated and in vitro expanded in $17 \pm 4$ days up to $300 \pm 20$ millions. Cells were cultivated in a complete human medium, using the own patient serum obtained from patient blood sample (one case) and from patient plasmapheresis (five cases). To obtain a pure myoblast culture, fibroblasts were progressively eliminated from the flasks using the pre-plat- 
ting technique. At the moment of implantation, the rate of myoblasts was $82 \pm 5 \%$ and the rate of viable cells 95 $\pm 3 \%$. Afterwards the cells diluted in human albumin and culture medium were placed in a syringe ready to be injected. During a surgical procedure, through sternotomy CABG was performed (1.7 grafts/patient). The muscle cells were then injected through $6 \pm 2$ injection points into the posterior wall of the left ventricle, into and around the infarcted areas, using a $25 \mathrm{G} \times 40 \mathrm{~mm}$ retrobulbar ophthalmic needle.

Preliminary Results: Patients had uneventful recovery and were discharged from the ICU 2 days after surgery. At a mean follow-up of $6 \pm 2$ months no cardiac arrhythmias were recorded. Echocardiographic studies showed improvement of regional myocardial motion (from akinetic scars to hypokinetic ventricular wall), regional fractional shortening improved from $9 \pm 3 \%$ to 20 $\pm 5 \%(\mathrm{p}<0.05)$. The infarct scars size appear to be significantly reduced: from $21 \pm 5 \mathrm{~cm} 2$ to $8 \pm 3 \mathrm{~cm}^{2}$ (p < 0.05 ). Myocardial viability tests showed regenerating nodes. Patients moved from heart failure class III to class I.

\section{Conclusions}

Our clinical results contrast with observations reported by other investigators using fetal bovine serum (FBS) for cell culture and in which $40 \%$ of patients required defibrillator implantation [19]. Using FBS results in a 3week contact and fixation of animal proteins in the cell surface, representing an antigenic and inflammatory substrate for immunological adverse events. Moreover, the cells expanded with FBS must be strongly washed before human implantation, resulting in cellular injury. Importantly, the use of autologous human serum for cell cultures does not carry any risk of prion, viral or zoonoses contaminations.

Obtaining serum from patient blood sample has the limitation of the amount of blood that can be drawn from the patient. However, the use of plasmapheresis allows a significantly larger supply of serum to be obtained as there is no loss of patient blood cells during the procedure thus providing a remarkable benefit for the patient and for ICU hemodynamic management.

The technical approach used to implant the cells should influence on the efficacy of cellular cardiomyoplasty. Cell mortality after transplantation seems to be important when they are grafted in the center of high-fibrotic ischemic scars, since there is a great limitation of oxygen and nutrients supply to the chronic ischemic my- ocardium. Implanting the cells mainly in the periinfarct areas may improve the rate of surviving cells, thus the size of the infarct scar undergoes a centripetal reduction. Cells should be injected by multiple points depending of the size and the configuration of the myocardial diseased area. New developed percutaneous endoventricular catheters can be used for cell delivery instead of surgery $[17,20]$. However, the precise localization of the diseased myocardium to be treated by cells is still a challenge.

Future research programs should be oriented on the preconditioning for predifferentiation of stem cells before transplantation, the optimization of the rate of surviving cells after myocardial implantation, and the improvement of host myocardium-transplanted cell interactions [21-24]. Ventricular electrostimulation should play an important role in transforming a passive cell-based procedure to a "dynamic cellular support" [12].

\section{References}

1. Chachques JC, Carpentier A. Cellular myoplasty: what are we really trying to achieve? J Thorac Cardiovasc Surg 2002;123:583-4.

2. Quaini F, Urbanek K, Beltrami AP, Finato N, Beltrami CA, NadalGinard B, Kajstura J, Leri A, Anversa P. Chimerism of the transplanted heart. N Engl J Med 2002;346:5-15.

3. Chachques JC, Cattadori B, Carpentier A. Dynamic to cellular cardiomyoplasty. In: Franco KL, Verrier ED, eds. Advanced therapy in cardiac surgery, 2nd edn., Chapter 44. Hamilton, Ontario, Canada: Decker, in press.

4. Scott-Burden T, Bosley JP, Rosenstrauch D, Henderson KD, Clubb FJ Jr, Eichstaedt HC, Eya K, Gregoric I, Myers TJ, Radovancevic B, Frazier $\mathrm{OH}$. Use of autologous auricular chondrocytes for lining artificial surfaces: a feasibility study. Ann Thorac Surg 2002;73: 1528-33.

5. Maisch B, Ristic AD, Hufnagel G, Funck R, Alter P, Tontsch D, Pankuweit $S$. Dilated cardiomyopathies as a cause of congestive heart failure. Herz 2002;27:113-34.

6. Carpentier A, Chachques JC, Grandjean P, eds. Cardiac bioassist. New York: Futura, 1997:1-632.

7. Taylor DA, Atkins BZ, Hungspreugs P, Jones TR, Reedy MC, Hutcheson KA, Glower DD, Kraus WE. Regenerating functional myocardium: Improved performance after skeletal myoblast transplantation. Nature Med 1998;4:929-33.

8. Dorfman J, Duong M, Zibaitis A, Pelletier MP, Shum-Tim D, Li C, Chiu RCJ. Myocardial tissue engineering with autologous myoblast implantation. J Thorac Cardiovasc Surg 1998;116:744-51.

9. Rajnoch C, Chachques JC, Berrebi A, Bruneval P, Benoit MO, Carpentier A. Cellular therapy reverses myocardial dysfunction. J Thorac Cardiovasc Surg 2001;121:871-8.

10. Burlew BS, Weber KT. Cardiac fibrosis as a cause of diastolic dysfunction. Herz 2002;27:92-8.

11. Fedak PWM, Weisel RD, Yau TM, Mickle DAG, Li RK. Cell transplantation, ventricular remodeling, and the extracellular matrix. J Thorac Cardiovasc Surg 2002;123:584-5.

12. Chachques JC, Shafy A, Cattadori B, Duarte F, Shen L, Meimoun P, Argyriadis $P$, Bruneval $P$, Carpentier A. Electrostimulation en- 
hanced fatigue resistant myosin expression in cellular cardiomyoplasty. Circulation 2001;104:Suppl 2:555-6.

13. Tomita S, Mickle DA, Weisel RD, Jia ZQ, Tumiati LC, Allidina Y, Liu P, Li RK. Improved heart function with myogenesis and angiogenesis after autologous porcine bone marrow stromal cell transplantation. J Thorac Cardiovasc Surg 2002;123:1132-40.

14. Orlic D, Kajstura J, Chimenti S, Jakoniuk I, Anderson SM, Li B, Pickel J, McKay R, Nadal-Ginard B, Bodine DM, Leri A, Anversa P. Bone marrow cells regenerate infarcted myocardium. Nature 2001;410 $701-5$.

15. Jiang $\mathrm{Y}$, Jahagirdar BN, Reinhardt RL, Schwartz RE, Keene CD, Ortiz-Gonzalez XR, Reyes M, Lenvik T, Lund T, Blackstad M, Du J, Aldrich S, Lisberg A, Low WC, Largaespada DA, Verfaillie CM. Pluripotency of mesenchymal stem cells derived from adult marrow. Nature 2002;418:41-9.

16. Suzuki K, Murtuza B, Suzuki N, Smolenski RT, Yacoub MH. Intracoronary infusion of skeletal myoblasts improves cardiac function in doxorubicin-induced heart failure. Circulation 2001;104: 1213-7.

17. Chachques JC, Blanchard D, Shafy A, Argyriadis P, Fabiani JN, Guermonprez JL, Carpentier A. Implantation de myoblastes dans le myocarde par voie endoventriculaire. Arch Mal Coeur 2001;94:1428.

18. Chachques JC, Duarte F, Cattadori B, Meimoun P, Illiou MC, Fabiani JN, Carpentier A. Angiogenic growth factors versus cellular therapy for myocardial infarction. Presented at the American Association for Thoracic Surgery (AATS), 82nd Annual Meeting. Abstracts Book 2002, page 68, abstract F17.

19. Hagege AA, Vilquin JT, Bruneval P, Menasche P. Regeneration of the myocardium: a new role in the treatment of ischemic heart disease? Hypertension 2001;38:1413-5.

20. Strauer BE, Brehm M, Zeus T, Gattermann N, Hernandez A, Sorg RV, Kogler G, Wernet P. Intracoronary, human autologous stem cell transplantation for myocardial regeneration following myocardial infarction. Dtsch Med Wochenschr 2001;126:932-8.
21. Chachques JC, Hidalgo J, Cattadori B, Duarte F, Shafy A, Argyriadis P, Fabiani JN, Carpentier A. Cardiomioplastia celular: un nuevo enfoque terapeutico para la disfuncion ventricular. Intercont Cardiol 2001;10:11-5.

22. Hamano K, Nishida M, Hirata K, Mikamo A, Li TS, Esato K, Harada $M$, Miura T. Preliminary results of clinical trials of therapeutic angiogenesis achieved by the implantation of self bone marrow cells for ischemic heart disease. Circulation 2001;104:Suppl 2:69.

23. Stamm C, Westphal B, Kleine B, Petzsch M, Schümichen C, Nienaber $C$, Freund $M$, Steinhoff $G$ : Bone marrow stem cell transplantation for regeneration of infarcted myocardium in CABG patients at Rostock University. Abstracts Book, 16th Annual Meeting EACTS, Monaco, September 22-25, 2002.

24. Chachques JC, Shafy A, Duarte F, Cattadori B, Shen L, Meimoun P, Carpentier A. From dynamic cardiomyoplasty to cellular cardiomyoplasty. Acta Chirurgica Austriaca 2001;33:Suppl 175:24-5.

\author{
Correspondence Address \\ Juan C. Chachques, MD, PhD \\ Department of Cardiac Surgery \\ Pompidou Hospital \\ 20 rue Leblanc \\ 75015 Paris \\ France \\ Phone (+33/1) 43959359, Fax 40728608 \\ e-mail: j.chachques@brs.ap-hop-paris.fr
}

